\title{
AGRICULTURAL ECONOMIC STRUCTURE TRANSFORMATION IN PHO YEN TOWN, THAI NGUYEN PROVINCE
}

\author{
Ngo Van Duong ${ }^{1}$, Nguyen Van Tam ${ }^{2 *}$, Ha Thi Hoa ${ }^{2}$, Tran Nho Huong \\ ${ }^{1}$ People's Committee of Pho Yen town, Thai Nguyen province \\ ${ }^{2} T N U$ - University of Agriculture and Forestry \\ ${ }^{3}$ Thai Nguyen Department of Agriculture and Rural Development
}

\section{ABSTRACT}

The study aimed to assess the situation and propose solutions for agricultural economic structure transformation in Pho Yen town, Thai Nguyen province. Descriptive statistical method, comparison method and SWOT analysis method were used. The results show that agricultural economic structure in Pho Yen town, Thai Nguyen province has transformed in a positive direction, gradually reducing the proportion of cultivation, increasing the proportion of livestock and service. Total investment capital for agriculture increased sharply, the capital in 2017 increased by $3.49 \%$ compared to 2016 . In 2018 , it increased by $82.78 \%$ compared to 2017 . The study also proposed four groups of solutions to promote agricultural economic structure transformation in Pho Yen town, including: improving the quality of production planning; implementing effectively the land policy; completing mechanism and policy to encourage and support production development and restructuring agriculture; developing sustainably industry and supporting service to promote agricultural economic structure transformation.

Keywords: Agricultural economic structure; agricultural economic structure transformation; crop economic structure; livestock economic structure; Pho Yen town

Received: 25/02/2020; Revised: 30/3/2020; Published: 30/3/2020

\section{CHUYỂN DICCH CƠ CÁU KINH TẾ NÔNG NGHIỆP TRÊN ĐỊA BÀN TH!̣ XÃ PHỔ YÊN, TỈNH THÁI NGƯYÊN}

\author{
Ngô Văn Dưỡng1, Nguyễn Văn Tâm²*, Hà Thị Hòa ${ }^{2}$, Trần Nho Hưởng ${ }^{3}$ \\ ${ }^{1}$ Ủy ban nhân dân thị xã Phổ Yên, tỉnh Thái Nguyên \\ ${ }^{2}$ Truờng Đại học Nông Lâm - ĐH Thái Nguyên \\ ${ }^{3}$ Sở Nông nghiệp \& Phát triển nông thôn tỉnh Thái Nguyên
}

\section{TÓM TẮT}

Nghiên cứu được thực hiện nhằm đánh giá thực trạng và đề xuất các giải pháp nhằm chuyển dịch cơ cấu kinh tế nông nghiệp trên địa bàn thị xã Phổ Yên, tỉnh Thái Nguyên. Nghiên cứu sử dụng phương pháp thống kê mô tả, phương pháp so sánh và phương pháp phân tích SWOT. Kết quả nghiên cứu cho thấy cơ cấu kinh tế nông nghiệp trên địa bàn thị xã Phổ Yên, tỉnh Thái Nguyên chuyển dịch theo hướng tích cực, giảm dần tỷ trọng trồng trọt, tăng dần tỷ trọng chăn nuôi và dịch vụ. Tổng nguồn vốn đầu tư cho phát triển nông nghiệp tăng mạnh, năm 2017 nguồn vốn tăng 3,49\% so với năm 2016; năm 2018 mức tăng lên đến 82,78\%. Nghiên cứu cũng đề xuất bốn nhóm giải pháp nhằm đẩy mạnh chuyển dịch cơ cấu kinh tế nông nghiệp trên địa bàn thị xã Phổ Yên, gồm: Nâng cao chất lượng công tác quy hoạch; Thực hiện hiệu quả chính sách đất đai; Hoàn thiện cơ chế, chính sách khuyển khích, hỗ trợ phát triển sản xuất và thực hiện tái cơ cấu ngành nông nghiệp; Phát triển bền vững công nghiệp và dịch vụ hỗ trợ thúc đẩy chuyển dịch cơ cấu kinh tế nông nghiệp theo hướng đô thị hóa.

Từ khóa: Cơ cấu kinh tế nông nghiệp; chuyển dịch co cấu kinh tế nông nghiệp; co cấu ngành trồng trọt; cơ cấu ngành chăn nuôi; thị xã Phổ Yên.

Ngày nhận bài: 25/02/2020; Ngày hoàn thiện: 30/3/2020; Ngày đăng: 30/3/2020

* Corresponding author. Email: nguyenvantam@tuaf.edu.vn

DOI: https://doi.org/10.34238/tnu-jst.2020.03.2728 


\section{Introduction}

Agricultural economic structure transformation is a development process of the agricultural sector, leading to the growth of different sectors and changing the interaction between them compared to the previous period [1]. Agricultural economic structure transformation plays an important role for agriculture in particular and whole economy in general. Agricultural economic structure transformation associated with the social labour redistribution. Reasonable agricultural economic structure transformation enables agriculture quickly adapting to the requirement of integration, expansion of international cooperation and contributes to the effective maintenance of a multi-sector commodity economy. Reasonable agricultural economic structure transformation also contributes to successful implementation of industrialization and modernization, implementing export-oriented strategy, gradually changing to knowledge economy.

In recent years, agricultural economic structure transformation in Pho Yen town, Thai Nguyen province has got outstanding results. The agricultural economic structure has been changed towards industrialization and modernization, focusing on production in the direction of high value products and the contribution of agriculture to the town's budget increased. However, comparing to the advantages and potentials, agricultural economic structure transformation in Pho Yen town still has many problems [2].

This study is conducted with two objectives: (i) Assessing the situation of agricultural economic structure transformation in Pho Yen town in the period 2014-2018; (ii) Proposing solutions to promote agricultural economic structure transformation.

\section{Research methodology}

\subsection{Methodology for research area selection}

Based on secondary data sources, we selected three communes and wards, including: Dong Tien ward, Bac Son ward, Thuan Thanh commune, representing communes and wards with three levels of agricultural economic structure transformation: fast, medium and slow level.

\subsection{Methodology for data collection}

We collect available information and data on the natural, socio-economic condition of Pho Yen town from the Department of Economics, Statistics Office, People's Committee of communes and wards.

The method of convenience sampling [3] was used. Because of time and financial limitation, we investigated and interviewed 30 households and 10 officials each commune and ward. Totally, 90 farmers and 30 officials were investigated.

From the collected results, it is possible to make a more general and objective assessment of the research

\subsection{Methodology for data analysis}

\subsubsection{Descriptive statistics method}

This method is applied to describe the collected, investigated data and to assess results

\subsubsection{Comparative method}

This method is used to compare average numbers and the influence of factors on agricultural economic structure transformation of Pho Yen town.

\subsubsection{SWOT analysis method}

SWOT analysis is used to identify strength, weaknesses, opportunities, and threats for agricultural economic structure transformation in Pho Yen town. From this analytical result, it is possible to propose solutions with the purposes of promoting strength, taking opportunity, pushing back weaknesses and overcoming future threats.

\section{Result and discussion}

\subsection{Natural and socio-economic condition in Pho Yen town, Thai Nguyen province}

\subsubsection{Natural condition}

Pho Yen is a midland town located in the southern part of Thai Nguyen province. Its map is shown in Figure 1. The topography of Pho Yen is lower from the northwest to the southeast. Pho Yen climate is tropical monsoon with two distinct hot and cold seasons. The hot season is from April to October with so much rain. The cold season is from November to march next year. Due to the socio-economic condition with rapid urbanization in both urban and rural areas, it 
has led to a change in the land use structure of the town to adapt with the requirement of socio-economic development. According to the land statistic, the land structure of Pho Yen town in 2018 is: agricultural land: $19,148.78$ ha $(75.26 \%)$; non-agricultural land: $4,923.03$ ha $(24.65 \%)$; unused land: 22.90 ha $(0.09 \%)$ [2].

\subsubsection{Socio-economic condition}

In the period 2016 - 2018, Pho Yen town has reached breakthrough results in economic development. The total production value increased sharply from 440,075 billion VND in 2016 to 605,713 billion VND in 2018, an average increase of $17.32 \%$ per year. The total population in Pho Yen town in 2018 was 193,834 people. The population living in urban areas increased sharply from 38,980 people in 2016 to 55,058 people in 2018 , an average increase of $14.98 \%$ per year. The biggest change was from 2017 to 2018 (urban population increased by 14,973 people). The reason is due to that Pho Yen district was upgraded to a town in 2015. This upgrade has transformed some central communes into wards, which has led to a sharp increase in the number of urban population. The situation of population in Pho Yen town was shown in Table 1.

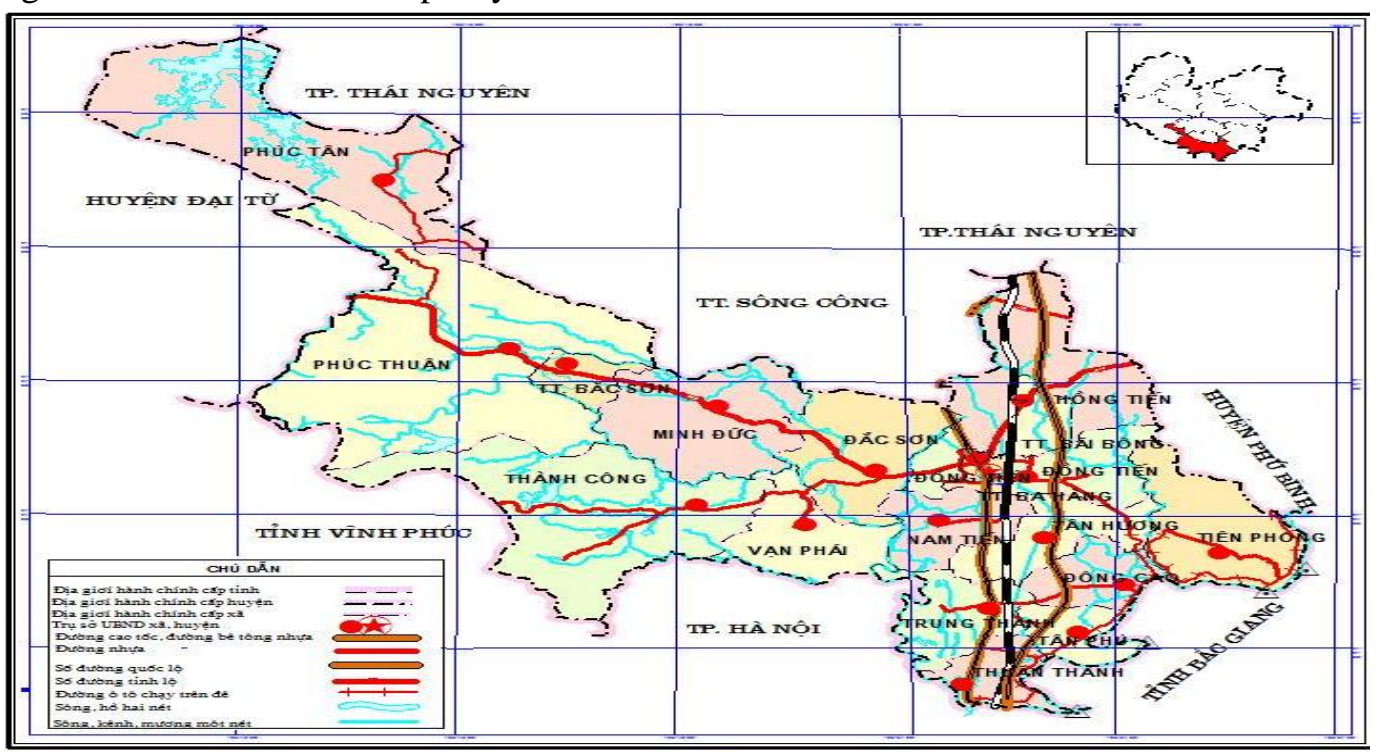

Figure 1. Map of Pho Yen town [4]

Table 1. Situation of population in Pho Yen town in the period 2016 -2018 [5]

\begin{tabular}{|c|c|c|c|c|c|}
\hline \multirow{2}{*}{ Year } & \multirow{2}{*}{ Total } & \multicolumn{2}{|c|}{ By gender } & \multicolumn{2}{|c|}{ By urban and rural areas } \\
\hline & & Male & Female & Urban & Rural \\
\hline \multicolumn{6}{|c|}{ I. Population (People) } \\
\hline 2016 & 172,040 & 83,355 & 88,685 & 38,980 & 133,060 \\
\hline 2017 & 173,945 & 84,139 & 89,806 & 40,055 & 133,890 \\
\hline 2018 & 193,834 & 89,426 & 104,408 & 55,028 & 138,806 \\
\hline \multicolumn{6}{|c|}{ II. The rate of increase (\%) } \\
\hline 2016 & 0.4 & 0.4 & 0.4 & 4.8 & -0.8 \\
\hline 2017 & 1.1 & 0.9 & 1.3 & 2.8 & 0.6 \\
\hline 2018 & 1.4 & 6.3 & 6.3 & 7.4 & 3.7 \\
\hline \multicolumn{6}{|c|}{ III. Proportion (\%) } \\
\hline 2016 & 100 & 48.45 & 51.55 & 22.66 & 77.34 \\
\hline 2017 & 100 & 48.37 & 51.63 & 23.03 & 76.97 \\
\hline 2018 & 100 & 46.14 & 53.86 & 28.39 & 71.61 \\
\hline
\end{tabular}


3.1.3. General assessment of natural and socio-economic conditions for agricultural economic structure transformation in Pho Yen town.

\subsubsection{Advantage}

Pho Yen has the convenient transportation system, adjacent to Hanoi capital, relatively flat terrain, fertile soil, mild climate and abundant human resources ... They are very convenient for economic development in general and for agricultural economic structure transformation in particular.

Agricultural economic structure transformation always receives the attention and leadership of the Party Committee, People's Council, People's Committee of the town, the assistance and facilitation of Thai Nguyen and the support of research and technology transfer agencies.

Extension staff, veterinary staff, plant protection staff has been strengthened, agricultural extension activities towards agricultural economic structure transformation continues to be concerned.

\subsubsection{Difficulty}

Abnormal weather affects agricultural production results, making difficulty for agricultural economic structure transformation.

Prices of agricultural economic structure transformation materials and fertilizers are high, so intensive investment in agricultural production and agricultural economic structure transformation is limited.

The labor force in the agricultural sector faces many difficulties, mainly the elderly, as the working-age laborers participate in industry, services and other non-agricultural fields.

3.2. Situation of agricultural economic structure transformation in Pho Yen town in the period 2014-2018

Pho Yen town was originally considered as one of the major agricultural production areas of Thai Nguyen province, but in recent years, a part of agricultural land has been recovered for projects. Agricultural production value of Pho Yen town in the period 2014-2018 is shown in table 2.

Table 2 shows that $100 \%$ of agricultural production value in Pho Yen town is from non-state economy. Classifying by economic sector (agriculture, forestry, fishery), agricultural production value is accounted for $97 \%$ of total agricultural production value. In particular, in 2014 the production value reached 1.325.000 million VND (96.32\%), in 2018 , the production value got 1.811 .900 million VND, accounting for $97.32 \%$. The structure of agricultural production tends to increase with the average growth rate of $8.3 \% / y e a r$.

Table 2. Agricultural production value of Pho Yen town in the period 2014-2018 [5]

\begin{tabular}{lccccc}
\hline Indicator & $\mathbf{2 0 1 4}$ & $\mathbf{2 0 1 5}$ & $\mathbf{2 0 1 6}$ & $\mathbf{2 0 1 7}$ & $\mathbf{2 0 1 8}$ \\
\hline $\begin{array}{l}\text { Total } \\
\text { I, By economic ownership }\end{array}$ & $\mathbf{1 , 3 7 5 , 5 5 9}$ & $\mathbf{1 , 4 2 3 , 5 1 5}$ & $\mathbf{1 , 7 9 0 , 7 0 0}$ & $\mathbf{1 , 7 9 1 , 3 0 0}$ & $\mathbf{1 , 8 6 1 , 8 5 1}$ \\
$\begin{array}{l}\text { 1, State-owned economy } \\
\text { (million VND) }\end{array}$ & 0 & 0 & 0 & 0 & 0 \\
$\begin{array}{l}\text { 2, Non-state economy } \\
\text { (million VND) }\end{array}$ & $1,375,559$ & $1,423,515$ & $1,790,700$ & $1,791,300$ & $1,861,851$ \\
$\begin{array}{l}\text { II, By economic sector } \\
\text { 1, Agriculture (million VND) }\end{array}$ & $1,325,000$ & $1,378,929$ & $1,752,600$ & $1,747,300$ & $1,811,900$ \\
Structure (\%) & 96.32 & 96.87 & 97.87 & 97.54 & 97.32 \\
2, Forestry (million VND) & 22,057 & 14,537 & 7,100 & 9,900 & 11,627 \\
Structure (\%) & 1.60 & 1.02 & 0.40 & 0.56 & 0.62 \\
3, Fishery (million VND) & 28,502 & 30,049 & 31,000 & 34,100 & 38,324 \\
$\quad$ Structure (\%) & 2.08 & 2.11 & 1.73 & 1.90 & 2.06 \\
\hline
\end{tabular}




\subsubsection{Crop, livestock economic structure}

In agricultural economic structure of Pho Yen town, crop and livestock have developed harmoniously. Crop production structure tends to decrease in agricultural production structure. As shown in figure 2, this structure has decreased from $53.75 \%$ (in 2014) to $36.88 \%$ (in 2018). The reason is due that in recent years, a part of agricultural land has been recovered for projects, thus, the area of agricultural land decreases sharply.

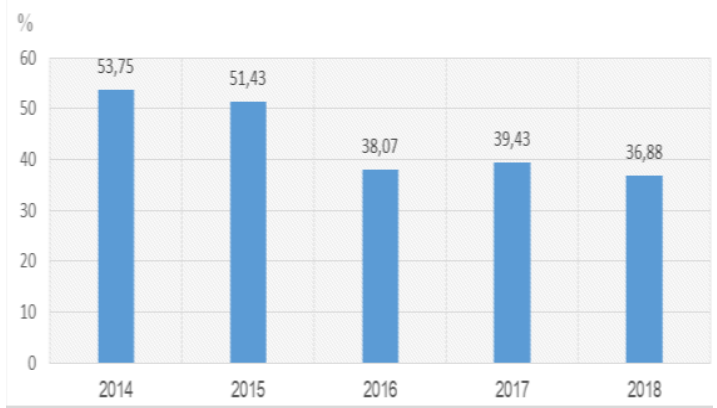

Figure 2. Crop production structure in the period $2014-2018$ [5]

Figure 3 shows that in the period 2014 - 2018, livestock sector of Pho Yen town had a positive shift, in 2014 the value of livestock production reached 542,811 million VND, accounting for $40.97 \%$ of the agricultural production value. In 2018, the value increased to $1,024,182$ million VND $(56.53 \%$ of the agricultural production value with the average growth rate of $20.06 \%$ /year. Livestock production of Pho Yen town focuses on raising cattle (buffaloes, cows, pigs) and poultry (chickens and ducks).

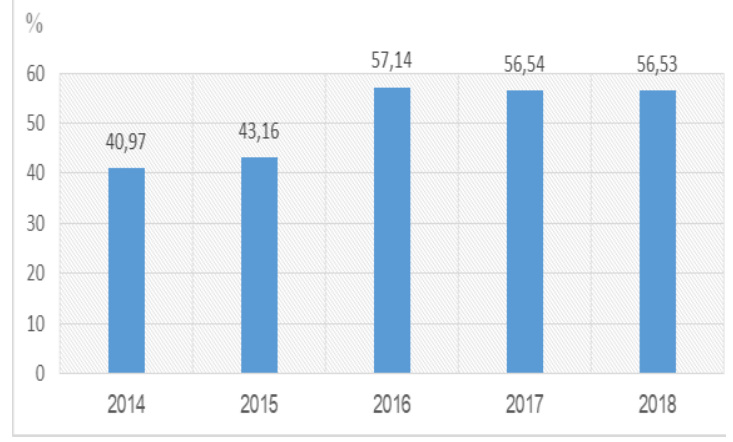

Figure 3. Livestock production structure in the period 2014 - 2018 [5]

\subsubsection{Forestry economic structure}

Forestry production value accounts for a small proportion (about 1\%) in agricultural economic structure and tends to decrease. In 2014, this value accounted for $1.6 \%$ of agricultural production value of Pho Yen town. In 2018, the value decreased and only accounted for $0.62 \%$. Although forestry production is not the strength of Pho Yen town, forestry production tends to change in the direction of increasing value and gradually socializing forest contraction and protection.

Table 3. Forestry production structure in the period 2014 - 2018 [5]

\begin{tabular}{|c|c|c|c|c|c|c|c|c|c|c|}
\hline \multirow[b]{2}{*}{ Indicators } & \multicolumn{2}{|c|}{2014} & \multicolumn{2}{|c|}{2015} & \multicolumn{2}{|c|}{2016} & \multicolumn{2}{|c|}{2017} & \multicolumn{2}{|c|}{2018} \\
\hline & $\begin{array}{c}\text { Value } \\
\text { (million } \\
\text { VND) }\end{array}$ & $\begin{array}{c}\text { Proportion } \\
(\%)\end{array}$ & $\begin{array}{c}\text { Value } \\
\text { (million } \\
\text { VND) }\end{array}$ & $\begin{array}{c}\text { Proportion } \\
(\%)\end{array}$ & $\begin{array}{c}\text { Value } \\
\text { (million } \\
\text { VND) }\end{array}$ & $\begin{array}{c}\text { Proportion } \\
(\%)\end{array}$ & $\begin{array}{c}\text { Value } \\
\text { (million } \\
\text { VND) }\end{array}$ & $\begin{array}{c}\text { Proportion } \\
(\%)\end{array}$ & $\begin{array}{c}\text { Value } \\
\text { (million } \\
\text { VND) }\end{array}$ & $\begin{array}{c}\text { Proportion } \\
\text { (\%) }\end{array}$ \\
\hline Total & 22,057 & 100 & 14,537 & 100 & 7,100 & 100 & 9,900 & 100 & 11,627 & 100 \\
\hline $\begin{array}{l}\text { Planting and } \\
\text { raising } \\
\text { forests }\end{array}$ & 1,610 & 7.30 & 1,402 & 9.64 & 684 & 9.63 & 2,323 & 23.46 & 2,718 & 23.38 \\
\hline $\begin{array}{l}\text { Forest } \\
\text { product } \\
\text { exploitation }\end{array}$ & 20,180 & 91.49 & 12,744 & 87.67 & 6,177 & 87.00 & 3,413 & 34.47 & 3,993 & 34.34 \\
\hline $\begin{array}{l}\text { Forest by- } \\
\text { products }\end{array}$ & 19 & 0.09 & 31 & 0.21 & 24 & 0.34 & 119 & 1.20 & 139 & 1.20 \\
\hline $\begin{array}{l}\text { Forestry } \\
\text { services }\end{array}$ & 248 & 1.12 & 360 & 2.48 & 215 & 3.03 & 4,045 & 40.86 & 4,777 & 41.08 \\
\hline
\end{tabular}


Table 3 shows that forest product exploitation brings the greatest value. However, in the development process, the forestry industry of Pho Yen town still faces many difficulties, such as production forest having low value (about 50 million VND/ha/5 years), small-scale planted forest area (1-2 ha/household)...

\subsubsection{Fishery economic structure}

Pho Yen town has 330 ha of water surface, which is a good condition for fishery development. However, the fishery production value only accounts for a small proportion (2.06\% in 2018). This result shows that Pho Yen government has not focused on fishery sector. Fishery production structure of Pho Yen town was shown in Table 4.

In order to guide households investing in fishery sector, Pho Yen town develops some programs and projects such as demonstration model of intensive farming of integrated fish (carp, drift...) in Dong Tien, Dong Cao, Tan Huong, Tien Phong, Dac Son and Van Phai; Model of fish farming combined with rice production in Tan Huong and Trung Thanh; Gift tilapia production mode... However, these models were not replicated because of low economic efficiency.

Table 4. Fishery production structure in the period 2014 - 2018 [5]

\begin{tabular}{|c|c|c|c|c|c|c|c|c|c|c|}
\hline \multirow[b]{2}{*}{ Indicators } & \multicolumn{2}{|c|}{2014} & \multicolumn{2}{|c|}{2015} & \multicolumn{2}{|c|}{2016} & \multicolumn{2}{|c|}{2017} & \multicolumn{2}{|c|}{2018} \\
\hline & $\begin{array}{l}\text { Value } \\
\text { (million } \\
\text { VND) }\end{array}$ & $\begin{array}{c}\text { Proportion } \\
\text { (\%) }\end{array}$ & $\begin{array}{l}\text { Value } \\
\text { (million } \\
\text { VND) }\end{array}$ & $\begin{array}{c}\text { Proportion } \\
(\%)\end{array}$ & $\begin{array}{l}\text { Value } \\
\text { (million } \\
\text { VND) }\end{array}$ & $\begin{array}{c}\text { Proportion } \\
(\%)\end{array}$ & $\begin{array}{l}\text { Value } \\
\text { (million } \\
\text { VND) }\end{array}$ & $\begin{array}{l}\text { Proportion } \\
\text { (\%) }\end{array}$ & $\begin{array}{l}\text { Value } \\
\text { (million } \\
\text { VND) }\end{array}$ & $\begin{array}{l}\text { Proportion } \\
(\%)\end{array}$ \\
\hline Total & 28,502 & 100 & 30,049 & 100 & 31,000 & 100 & 34,100 & 100 & 38,324 & 100 \\
\hline Aquaculture & 25,695 & 90.15 & 27,249 & 90.68 & 27,850 & 89.84 & 30,540 & 89.56 & 34,321 & 89.55 \\
\hline Fisheries & 660 & 2.32 & 555 & 1.85 & 872 & 2.81 & 1,165 & 3.42 & 1,309 & 3.42 \\
\hline $\begin{array}{l}\text { Fishery } \\
\text { service }\end{array}$ & 2,147 & 7.53 & 2,245 & 7.47 & 2,278 & 7.35 & 2,395 & 7.02 & 2,694 & 7.03 \\
\hline
\end{tabular}

\subsubsection{Agricultural service structure}

As presented in Table 5, in recent years, agricultural service in Pho Yen town have developed quickly, structure and value of agricultural service have tended to increase over the years.

Development of agricultural service has helped reducing costs, time, labour and contributed to increase productivity and efficiency of agricultural production. Many farmers in Pho Yen town have invested in buying combined harvesters, plows, and pesticide sprayers... However, Pho Yen government still does not have specific direction for the agricultural service sector. Therefore, the production value of agricultural service accounts for a low proportion (about 5\%) of the total agricultural production value of the town.

Table 5. Agricultural service structure in the period 2014-2018 [5]

\begin{tabular}{ccccc}
\hline \multirow{2}{*}{ Year } & \multicolumn{2}{c}{ Agricultural production value } & \multicolumn{2}{c}{ Agricultural service value } \\
\cline { 2 - 5 } & Value (million VND) & Proportion (\%) & Value (million VND) & Proportion (\%) \\
\hline 2014 & $1,375,559$ & 100 & 75,240 & 5.47 \\
2015 & $1,423,515$ & 100 & 77,206 & 5.42 \\
2016 & $1,790,700$ & 100 & 86,493 & 4.83 \\
2017 & $1,791,300$ & 100 & 100,340 & 5.60 \\
2018 & $1,861,851$ & 100 & 106,989 & 5.75 \\
\hline
\end{tabular}

\subsubsection{Investment capital for agricultural development}

It can be seen in Figure 4, in the period 2016 - 2018, the total investment capital for agriculture increased, in 2017, the capital source reached 18,456 million VND (increasing 3.49\% compared to 2016). In 2018, this capital reached 33,734 million VND (increasing $82.78 \%$ compared to 2017). This is a good sign for agricultural sector when attracting a large amount of investment capital, opening up many development opportunities for farmers. 


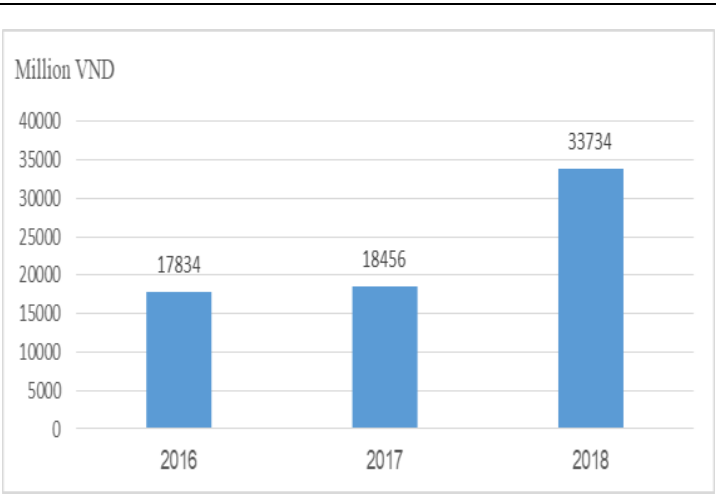

Figure 4. Investment capital for agricultural development in Pho Yen town Source [2]

3.2.6. Factors affecting on agricultural economic structure transformation in Pho Yen town

In order to promote agricultural economic structure transformation in Pho Yen town, we need to identify factors affecting on this process, thereby proposing the most effective solutions. The results of survey on officials and farmers are presented in Table 6.

According to officials and farmers, product consumption market has the greatest impact on agricultural economic structure. In fact, farmers can fully develop new production models, high-tech production models ... However, if their products cannot be sold, farmers will return to the old production methods.

Production planning: $86.67 \%$ officials and $94.44 \%$ farmers said that state's production planning greatly affects on agricultural economic structure transformation in Pho Yen town. Production planning will affect on the production tend, production area, the kind of plants and animals being developed. If production planning is not suitable, people will develop agriculture in a spontaneous, small and fragmented way. Xaysongkhame also reported a similar result when studying on agricultural economic structure transformation in Bo Keo province, Laos [6].

Production land area: $83.33 \%$ officials and $92.22 \%$ farmers answered that production land area affects on agricultural economic structure transformation. The fact in Pho Yen town shows that: the more production land a household has, the higher economic condition is, and the higher agricultural economic structure transformation takes place. In contrast, households with a small area of production land area are towards food selfsufficiency.

Preserving and processing agricultural products: $60 \%$ officials and $87.78 \%$ farmers said that preserving and processing agricultural products affects on agricultural economic structure transformation. Officials and farmers said that agricultural production is highly seasonal, in the main season, many products can not be sold or sold at low prices. Therefore, in order to invest and change their production transformation, preserving and processing agricultural products must develop correspondingly.

Table 6. Factors affecting on agricultural economic structure transformation in Pho Yen town

\begin{tabular}{lcccc}
\hline \multirow{2}{*}{ Factors } & \multicolumn{2}{c}{ Officials $(\mathrm{n}=30)$} & \multicolumn{2}{c}{ Farmers $(\mathrm{n}=90)$} \\
\cline { 2 - 5 } & $\begin{array}{c}\text { Number } \\
(\text { people })\end{array}$ & $\begin{array}{c}\text { Proportion } \\
(\%)\end{array}$ & $\begin{array}{c}\text { Number } \\
(\text { people })\end{array}$ & $\begin{array}{c}\text { Proportion } \\
(\%)\end{array}$ \\
\hline Product consumption market & 28 & 93.34 & 87 & 96.67 \\
Production planning & 26 & 86.67 & 83 & 94.44 \\
Production land area & 25 & 83.33 & 85 & 92.22 \\
Preserving and processing agricultural products & 18 & 60.00 & 82 & 87.78 \\
\hline
\end{tabular}




\subsubsection{SWOT analysis for agricultural economic structure transformation in Pho Yen town.}

In order to understand thoroughly about agricultural economic structure transformation in Pho Yen town., we used the SWOT analysis and the result was shown in table 7 and table 8.

Table 7. SWOT analysis for agricultural economic structure transformation

\begin{tabular}{|c|c|}
\hline Strength & Weakness \\
\hline 1. Urbanization and industrialization in Pho Yen & 1. Agricultural economic structure \\
\hline $\begin{array}{l}\text { 2. Location of Pho Yen is favorable for agricultural } \\
\text { economic structure transformation }\end{array}$ & $\begin{array}{l}\text { 2. Agricultural production being long production } \\
\text { cycle and high risk. }\end{array}$ \\
\hline $\begin{array}{l}\text { 3. Officials and local farmers responded positively } \\
\text { to agricultural economic structure transformation }\end{array}$ & $\begin{array}{l}\text { 3. Price of agricultural products is not stable, } \\
\text { largely dependent on domestic and foreign markets. }\end{array}$ \\
\hline 4. Income from agriculture is increasingly improved & $\begin{array}{l}\text { 4. Local farmers being lack of knowledge and } \\
\text { capacity }\end{array}$ \\
\hline Opportunity & Threats \\
\hline $\begin{array}{l}\text { 1. Vietnam government has policy to promote } \\
\text { agricultural economic structure transformation } \\
\text { 2. Science and technology help to increase } \\
\text { production value } \\
\text { 3. The demand for clean agricultural products is } \\
\text { increasing }\end{array}$ & $\begin{array}{l}\text { 1. Production planning still has problems } \\
\text { 2. Consumption market is not stable, depending } \\
\text { on external market } \\
\text { 3. Diversified commodity markets requiring } \\
\text { product diversification and improving product } \\
\text { quality }\end{array}$ \\
\hline
\end{tabular}

Source: Survey data, 2019

Table 8. Combined table of SWOT for agricultural economic structure transformation

\begin{tabular}{|c|c|}
\hline $\begin{array}{l}\text { 1. Applying the government's policy and taking } \\
\text { advantage of Pho Yen to promote urbanization and } \\
\text { industrialization. } \\
\text { 2. Applying efficiently advanced technology to } \\
\text { accelerate agricultural economic structure } \\
\text { transformation }\end{array}$ & $\begin{array}{l}\text { 1. Doing well the production planning to ensure } \\
\text { an effective and feasible planning } \\
\text { 2. Promoting market search for key products of } \\
\text { the Pho Yen town. }\end{array}$ \\
\hline $\begin{array}{l}\text { W/O } \\
\text { 1. Mobilizing resources, especially financial } \\
\text { resources, to help farmers enough investment } \\
\text { resources } \\
\text { 2. Promoting propaganda on agricultural economic } \\
\text { structure transformation and sustainable production }\end{array}$ & $\begin{array}{l}\text { 1. Helping farmers producing toward the market } \\
\text { demand } \\
\text { 2. Enhancing capacity and knowledge of the } \\
\text { local farmers }\end{array}$ \\
\hline
\end{tabular}

\subsection{Solutions for agricultural economic structure transformation in Pho Yen town, Thai Nguyen province}

\subsubsection{Improving the quality of production planning}

Production planning plays an extremely important role and has a significant orientation to agricultural economic structure transformation. In order to promote agricultural economic structure transformation, Pho Yen government needs to focus on adjusting the master plan for agricultural economic structure transformation; adjusting the development planning for each agricultural sector in the direction of focusing on each specific crop and livestock product to convert plants and animals with low value to plants and animals with high value. Especially, it is necessary to concentrate on production planning for key products of Pho Yen such as tea tree, fruit tree... 


\subsubsection{Implementing effectively land policy}

In order to effectively implement land policy, Pho Yen town needs to publicize the land use plan of agriculture, forestry and aquaculture after it has been approved by competent agencies for each production area and promote the process of land concentration in farms and large fields.

\subsubsection{Completing mechanism and policy to} encourage and support agricultural production development

Currently, almost households in Pho Yen town are small-scale households so the investment level per unit area is still low, not incentive for agricultural production. In addition, Pho Yen government needs to deploy more support for local farmers such as: supporting farmers through agricultural extension services, supporting human resource development, infrastructure development as a premise for agricultural production development...

3.3.4. Sustainably developing industry and supporting services to promote agricultural economic structure transformation

Industry and support service development will not only mobilize domestic and foreign resources, contribute to economic structure transformation in the direction of industrialization and modernization but also increase productivity capacity, quality and use value of agricultural products, reducing production costs per unit of product, increasing competitiveness of agricultural products in the market. In the coming time, Pho Yen needs to develop industry in urban areas and rural areas; pay attention for industry development to meet the input and output requirements (preservation and processing) of agricultural production; sustainable development of agricultural support services such as: supply of plant varieties, domestic animals, fertilizers, veterinary drugs, plant protection drugs, animal feeds, machines...

\section{Conclusion}

Pho Yen town has favorable natural and socio-economic condition for agricultural economic structure transformation. In the period 2014-2018, agricultural economic structure in Pho Yen town changed in a positive direction, gradually reducing the proportion of cultivation, gradually increasing the proportion of livestock and service. Total investment capital for agriculture increased sharply, in 2017 the capital increased by $3.49 \%$ compared to 2016; in 2018 the capital increased to $82.78 \%$ compared to 2017 . There are four groups of solution to promote agricultural economic structure transformation in Pho Yen town, including: improving the quality of production planning; effectively implementing land policy; completing mechanism and policy to encourage and support production development and restructure agriculture; sustainably developing industry and supporting service to promote agricultural economic structure transformation.

\section{REFERENCES}

[1]. T. T. Bui, Factors affecting on economic structure transformation in the industrialization period in Vietnam. Social Science Publishing House (in Vietnamese), 1997.

[2]. People's Committee of Pho Yen town, Socioeconomic development report in 2018, (in Vietnamese), 2019.

[3]. N. H. Ngoan, Agricultural statistics. Agricultural Publishing House, 2005.

[4]. People's Committee of Pho Yen town, Summary report on environment and resources in 2018 (in Vietnamese), 2019.

[5]. Statistical Office of Pho Yen Town, Pho Yen Town Statistical Yearbook, 2014, 2015, 2016. 2017, 2018 (in Vietnamese), 2019.

[6]. P. Xaysongkhame, N. H. Ngoan, "Study on agricultural economic structure transformation towards commodity production in Bo Keo province, Laos," Journal of Science and Development, vol. 13, no. 4, pp. 1496-1506, 2015. 